\title{
ARTICLES
}

\section{SEPARATION OF POWERS: AN ISLAMIC PERSPECTIVE ${ }^{1}$}

\author{
Mohammad Hashim Kamali*
}

\section{Introduction}

European colonialism dominated the Muslim world through much of the $19^{\text {th }}$ and $20^{\text {th }}$ centuries, during which time the Shari' ah was suppressed and supplanted by western legal codes and its nation-state model. This model, with it concomitant constitutional blueprint, became widespread in the emerging Muslim states that were also ruled by western educated elites more familiar with western doctrines than their own Islamic heritage. Yet the latter part of $20^{\text {th }}$ century witnessed a move in the opposite direction. Islamic revivalism of the closing decades of $20^{\text {th }}$ century espoused a mass protest over the failure of good governance and democracy in much of the post-colonial Muslim world. Muslim masses protested against western subjugation of their history and culture. The emerging voices thus conveyed the demand that law and governance in the Muslim lands must reflect their own heritage and values - hence the increasing tendency and demand in recent decades for an Islamic system of rule and constitution.

This article explores the principle of separation of powers and its proper constitutional role in regulating relations among the various organs of state in an Islamic polity. It will be noted at the outset that the Muslim polity has undergone shifting paradigms - from the Righteous Caliphate of the early decades of the advent of Islam, to the ensuing hereditary/dynastic caliphate, to western nation state, and now to a fresh demand for an Islamic state (dawla Islämiyya) as I explain in the following paragraphs. With the spread, under European influence, of the western nation state in much of the post-colonial Muslim world, both the Shari'ah and ulama lost their preeminence. Massive dislocations in their legal and political orders brought the Muslims face to face with a host of uncertainties as to what role, if any, their own legacy could play under the new constitutional arrangement of western origin.

Western educated elites that occupied the echelons of power in much of the post-colonial Muslim world found themselves ill at ease to activate the traditional channels of communication with their ulama and scholars. Muslim countries thus underwent sustained political turmoil that entailed military coup d'états and failure of good governance almost everywhere. It is still too early to say, for many Muslim countries, as to whether they have regained equilibrium and found 
their bearings with their respective constitutional orders. Are they in a position to develop their own methods and a congenial system of rule that strikes harmony with their hallowed values, and the modern law principles of constitution and separation of powers?

This article advances two opposing perspectives about the recognition or otherwise of separation of powers in an Islamic polity. One is that of administrative centralism that visualises a unitarian approach to government hierarchy and a strong executive organ that dominates the other branches of government leaving little room for a meaningful system of checks and balances by the various organs among themselves.

The second position it discusses maintains that separation of powers is not only valid in principle but that in a real sense the Islamic polity has consistently applied it. Thus it is held that a functional separation of powers had always existed and must therefore be recognised, especially in light of the prevailing conditions in much of the present-day Muslim world, which has accepted the western nation state model, a democratic constitution and its blueprint on separation of powers. The remainder of this article devotes a section each to a discussion of the three organs of state with a view to ascertain, in some detail, the status of the constitutional separation of powers and their supportive Islamic doctrines.

\section{Executive Centralism}

If the historical caliphate is taken as a basis of assessment, then it would appear that the head of state is the repository of all political power and that separation of powers, which is a requirement of political democracy, does not have a basis in an Islamic polity. The advocates of this view maintain that separation of powers is alien to the Islamic system. There is a basis for this opinion, as I shall explain, although I believe that this conclusion is less than accurate and calls for a fresh interpretation and assessment.

The centralist approach to governance is predicated on a certain reading of the doctrine of Divine Oneness (tawhid) and its far-reaching ramifications in Islamic political thought. Thus it is understood that Islam takes a holistic approach to governance both from within and without. The internal manifestation of this unitarian approach is seen in political and administrative centralism that unifies all parts of the Islamic polity into a central command structure that stands at the opposite pole of separation of powers. This unitarian approach is also manifested in the absence of any clear lines of division between religion and state, which are not separated from one another.

To say that caliphate had no place for separation of powers is predicated on the analysis that the caliph is designated into office by the people according to the principles of wakāla (representation) and walaya (delegated authority 
that originally belongs to the umma). The head of state, being the wakil or representative of the community by virtue of a contract of agency/representation thus becomes the repository of all political power. He is authorised, in turn, to delegate his powers to other government office holders, ministers, governors and judges etc. These are, then, entrusted with delegated authority (wilāyat), which they exercise on behalf of the head of state each in their respective capacities. Walāya is of two types, namely general (walāya 'ämma) such as that of ministers and governors, and specific (walāya khässa), which is task-specific and consists mainly of implementation rather than exercise of political power and policy initiatives. One who discharges general walāya must have comprehensive knowledge of the subject matter that falls under his jurisdiction, but one who exercises specific walaya need not have that level of knowledge. ${ }^{1}$

One of the principal assignments of the head of state is to implement the Shari'ah and in doing so to solicit assistance of all his employees and subordinates. The position of the head of state vis-à-vis the Shari' ah in this regard is seen as primarily administrative one that consists of an orderly execution of Shari'ah. The head of state is also authorised to take discretionary measures, under the rubric of siyāsa shar 'iyya, or Shari'ah-oriented policy, to ensure good management of public affairs. The measures so taken may or may not have been stipulated by the Shari'ah, nor in the more elaborate corpus juris of fiqh, but founded in judicious policy, experience and insight ( firāsa) of the leader. With the exception of judges whose position in respect of enforcing the Shari'ah is parallel to that of the caliph himself, all other officials act, in effect, as delegates and assistants to the head of state. ${ }^{2}$ Appointment of officials to government positions, another important task of the head of state, must strictly be on merit, which is predicated in two main principles: trustworthiness and strength. ${ }^{3}$ The latter refers to the relevant qualification and knowledge of the employee in relation to the work he is assigned to do. The best-qualified candidate for the post must be given priority over others.

Under the centralist model, government officials exercise delegated authority in the capacity either of leading officers of state who are vested with political authority, or hukm, or in the capacity of assistants (mu'âwinün) who do not exercise political authority and merely assist those who do. The leading officers are in turn assisted by deputies and assistants who act as administrators and managers but do not exercise political power or hukm. In sum, the centralist model did not recognise autonomous individuals and organs in government hierarchy who did not refer for authorisation to the head of state. ${ }^{4}$ The one exception to this, although somewhat half-heartedly made in earlier writings, is that of the judge whose position, in respect of the administration of Shari' ah, is at par with that of the head of state himself. ${ }^{5}$ 
Administration of the Shari' ah is a major duty, although evidently not the only one, of the head of state. This much is obvious, even in the typical outline of the ten duties of the head of state/caliph as listed in the renowned works of al-Mawardi, al-Farra' ${ }^{6}$ and others. These duties may be summarised as follows: protection of the religion; settlement of disputes among people; internal security; defence of the borders; enforcement of the hudud penalties; waging jihad against the enemies of Islam; collection of taxes; distribution of the assets of the public treasury to deserving parties; recruitment of officials; and personal supervision of state affairs. ${ }^{7}$

An important aspect of the foregoing analysis that hardly features in pre-modern writings on the subject is that a great deal of what is said on the subject matter of constitutional law, and more specifically, separation of powers, can properly be said to be of concern to siyāsah shar'iyyah (Shariah-oriented policy). Siyāsah refers mainly to policy initiatives, administrative and procedural measures taken in the interest of establishing justice and good governance. As a principle of Islamic public law, siyāsah shar'iyyah (or simply siyāsah) entrusts the head of state with discretionary powers to introduce measures and policy decisions, as well as extraShariah initiatives on matters of concern to the good management of public affairs that will ensure the orderly implementation of the Shari'ah. This may include economic development, military affairs, international relations, emergency situations and so forth. The urgency of situational development that demands attention may sometimes be such as to necessitate a certain departure from some of the normal rules of fiqh and the ijtiha $\bar{d}$-based elaborations of Shariah. ${ }^{8}$

Executive power in the state hierarchy is delegated to ministers, governors, army commanders and others. Text book writers have in this connection distinguished between two types of Ministers. First, those with full authority, or wazir al-tafwi d, who is also vested with the exercise of political power, or $h u k m$, taking initiative and making decisions in all areas of government. This is equivalent to what is now known as prime minister. One who is appointed to this position must fulfil the same qualifications as the head of state himself. These may be summarised into three, namely knowledge, a just character, and wisdom ('ilm, 'adāla, hikma) - although many text books have enumerated several other conditions. The second ministerial portfolio is known as that of 'executive minister', or wazir al-tanfidh, and extends mainly to implementation of specified range of duties on behalf of the head of state, also not involving exercise of political power or hukm. The head of state may appoint any number of executive ministers, but only one prime minister. ${ }^{9}$ It may be noted in passing that this line of division between two types of ministers originate in juristic opinion of a circumstantial type as explained below - there being no substantive Shari' ah position on this and it is, as Mutawalli and Busyuni 'Abd Allah have both viewed, reflective of the exigencies of the Abbasid caliphate. ${ }^{10}$ 
A similar line of division has been noted between two types of governorates, one based on competence (imärat al-istikfa'), and the other based on subjugation (imārat al-istila ${ }^{\prime}$ ). The former is appointed by the head of state and exercises power much along the same lines as the leader himself, whereas the latter occupies the post through military power with which the head of state concurs - often for lack of a better option. This latter is indicative of "exceptional circumstances at a time when the Abbasid caliphate of Baghdad had lost much of its effective power and control over the territorial domains of the state."11 Al-Mawardi wrote, however, that the powers of governors are "confined to management of the army, policy initiatives for people's benefit, internal security and defence but do not extend to adjudication and issuance of judicial orders, nor to the levying of (new) taxation." 12

Delegation of power or walāya, in whatever form, does not derogate from the substance of personal accountability. Everyone is accountable for that which has been placed under his or her charge. This is the purport of the following Qur' anic directives:

"Every soul is in pledge/accountable for its deeds" (al-Mudaththir, $74: 38)$

"Devour not one another's properties by false means, nor proffer them to the rulers so that you sinfully usurp a portion of what belongs to others" (al-Baqarah, 2:188);

"Take not a stand over that of which you have no knowledge. Surely, the hearing, the sight, the mind- each of these shall be called to account." (al-Isra', 17:36).

Personal accountability (muḩāsaba) in these passages applies to all members of the Muslim community - from the head of state, to the head of the family unit, to all government employees, men and women, indeed to everyone, as is known from the text of a renowned hadith quoted below. The precedent of the Rightly-Guided Caliphs, especially that of the second caliph, 'Umar al-Khattab, records numerous instances whereby the caliph took to task many leading figures, powerful governors for wrongdoing during his tenure of office. ${ }^{13}$

\section{Separation of Powers - an Affirmative View}

Theoretical concerns over the implications of tawhìd and structural unity of government notwithstanding, functional lines of division of powers existed even under the historical caliphate. This is partly due to the role of the Shari'ah 
and influence of the ulama who acted as the interpreters of Shari'ah. Whereas management of public affairs, siyāsa and public policy were the concern mainly of political leaders, the ulama occupied themselves with fiqh and ijtihäd that consisted of juridical elaborations of the Shari'ah. The manner in which the rulers implemented the corpus juris of fiqh and Shari' ah was also of concern to judicious policy and siyāsa.

Tawhìd is not a monolithic principle. Rather it is best understood as unity in diversity, Oneness of the Creator, and multiplicity of the creation - as aptly put in al-Qaradawi's phrase wahdaniyyat al-khaliq wa ta'addudiyyat almakhluq - signifying unity of the purpose and diversity of the means towards it. This pluralistic dimension of Islamic thought is seen in its recognition, for instance, of the validity of other (monotheistic) religions, recognition of reasoned disagreement (ikhtiläf) and of scholastic interpretations and madhhabs etc. Tawhìd at the level of belief is not open to disagreement or pluralism. Beyond that almost every aspect of the existential world, the complexity of human mental and physical make-up and manifestations of life on the planet earth and beyond are exceedingly pluralistic and diversified.

Muslim scholars are also reluctant to extend the implications of a centralist organisation of state to anything more than an administrative approach that need not interfere with the essence of accountability, and acceptance also of functional lines of division of powers in the various organs of state. The head of state, although the supreme political ruler of the land, could not be an absolute ruler. For he is not only subject to the overriding authority of the umma and Shari'ah but also dependent on the support of the ulama and mujtahids (those qualified to carry out independent reasoning or $i j t i h \bar{a} d$ ) as well as under duty to conduct the affairs of state through consultation and consensus with the community. The contract of representation (wakäla) also endorses the republican substance of the Islamic system, and many of the necessary ingredients of a democratic approach to governance. ${ }^{14}$

The centralist model seems to have originated in a presumptive logic, which was in turn taken at face value from the juristic works of the ulama, presumably because it was deemed to bear greater harmony with the integrationist outlook of tawhīd and the territorial unity of caliphate. This was how the Prophet, pbuh, in his capacity as the head of state, and the Rightly-Guided caliphs after him were seen to have conducted the business of government during the early decades of the emergence of the state of Madina. Yet it may be said that the Madinan state was small in size and was involved in recurrent warfare that might have dictated a central command structure. It was due probably to the force of circumstance, rather than any doctrinal mandate that could be quoted in support of administrative centralism. It is also somewhat of a discrepant analogy to extend the ramifications 
of tawhi $\bar{i}$, which is essentially a theological concept, to state administration. To this effect, al-Sanhuri wrote that unity (wahda) of government in the territorial domain of the historical caliphate was reflected in a unified central authority (sulta markaziya Islämiyya), which was personified by the caliph. ${ }^{15}$ Having said this, al-Sanhuri also observed that a centralised state was not an inflexible rule and the historical pattern may be changed in the light of prevailing conditions. There is nothing in the sources of Shari'ah to impose a mandate in regards to the administrative structure of government. ${ }^{16}$ The matter thus remains open to considerations of public interest, consultation (mașlaha and shürā) and siyāsa. It is through these methods that necessary adaptation and adjustment in the organisational structure of the state could be devised and implemented.

On an historical note, it will be noted further that the caliphate also changed over time and underwent divergent phases of development that brought it in many ways closer to a decentralised system. The fall of Baghdad in the hands of the Mongols in mid-thirteen century CE led to the emergence of sultanates and principalities under local princes and commanders that gave rise to powerful dynasties, such as the Ghaznavids, Saljuqs, the Almohads, and Fatimids (Afghanistan, Persia, north Africa and Egypt respectively) that marked the emergence of decentralised units under the nominal authority of the caliphate of Baghdad. Politics of power and military domination in the remote geographical reaches of the caliphate thus drastically reduced the effectiveness of the hitherto prevailing centralised model. Many of the local rulers, Sultans and Amirs were not only autonomous but effectively more powerful in their own territories than the caliph of Baghdad. Yet they paid homage to Baghdad only as a semblance of political unity that also served the purpose of their continued legitimacy in office. But weaknesses in the centre and difficulties of transport and communication, cultural and linguistic differences tended to endorse the spread of the decentralised pattern over the greater part of the vast geographical domains of the caliphate. Yet the sentiment of Muslim unity under the concepts of umma and khiläfa remained strong enough to give the caliphate a new lease of life under the Ottomans, which was, however, a military power for the most part, and this too was met with eventual decline and demise when Ottoman Turkey succumbed to western pressure to declare its termination in 1924.

\section{Legislation and the Legislative Organ}

The requirement of the Islamic constitutional theory that mandates the state to implement the Shari'ah has led some commentators to the conclusion that there is no place for independent legislation in Islam, and no separate legislative organ is therefore needed to fulfil that role. The Shari'ah thus presented a major limitation 
on the legislative powers of the state so much so that the state throughout the Islamic history has shied away from claiming legislative authority unto itselflest it create a rival system of law to the Shari'ah.

The state never ceased, however, to issue administrative ordinances, decrees and by-laws, under such alternative names as nizām, ferman, nizamnama, usulnama and qānūn, mostly under the rubric of siyāsa. The state had no legislative organ with a specific assignment to promulgate law, simply because this role was mainly played by the ulama as the interpreters of Shari'ah and carriers of ijtihād and $i j m \bar{a} '$. Many commentators, including Mahmood Ahmad Ghazi, author of a book, State and Legislation in Islam, are of the view that the state in Islam is not vested with independent legislative authority beyond interpreting and implementing the Shari'ah. ${ }^{17}$

Wahba al-Zuhaily, has observed, however, that separation of powers is upheld in an Islamic polity, not only in functional terms, but as a matter of principle. Zuhaily thus wrote on a comparative note:

Islam validates the principle of separation of powers. This is because legislation in Islam ensues from the Qur'an and Sunna, consensus $(i j m \bar{a})$ of the umma, and ijtihād. All of these are independent of the head of state- nay but he is bound by them and by the conclusions drawn from them. The principle of $i j m \bar{a}$ ' in Islam manifests the will of the people ... Both the Islamic and western democracies reject despotism and consider the people as the locus of authority in political and government affairs. ${ }^{18}$

Representative assemblies have the authority, both under the present-day constitutions of Muslim countries, and western doctrines, to pass laws and regulations, but unlike the western democratic state model, which exercises sovereign legislative authority, its Islamic counterpart is primarily consultative and has limited legislative powers. ${ }^{19}$ Moreover, consultative assemblies and parliaments have a relatively short history in Muslim countries and have functioned in a constrained environment due mainly to the overarching Shari'ah and the prevalence also of an all-powerful executive organ. The centralist model has thus prevailed, not only through the longer stretch of Islamic history, but also during much of the post-colonial period, and persistently dominated the legislative and judicial branches. Historically, the learned ulama and mujtahids monopolised the fatwa-making role, ijtihād and ijm $\bar{a}$ ', and left little room for consultative assemblies and parliaments in the interpretation of Shari'ah.

Except for the Ottoman state, the Andalus and the Maghreb where historical records indicate the existence, on a limited scale, of consultative councils of the learned for deliberation over juridical and state matters, which was not devoid, 
however, of political overtones, Muslim states had no recognised legislative organs. It was well into the early $20^{\text {th }}$ century, and during the post-colonial period for the most part, that Muslim countries began to create consultative councils (majlis shürä) with limited powers that were also constrained by the presence usually of a strong executive organ and a powerful ulama class. In the history of Islamic government, the state has neither initiated nor articulated separation of powers as such, just as it did not issue a formal constitution either. Yet the argument for the functional separation of powers in an Islamic polity ensues from the inherent limitations concerning the powers of the rulers and judges, the role of the ulama, the substantive principles of justice and the state duty to implement the Shari'ah.

The jurists and mujtahids were not state functionaries and mainly acted in their capacities as pious individuals that served and interpreted the Shari'ah independently of the state. These religious leaders were civil society figures that gained prominence through their knowledge and community service and their standing in the mosque and madrasa. They served voluntarily as teachers and imams, as free-lance legal advisors, attended birth and burial ceremonies and thus became influential in their communities. Their intellectual contribution and leadership could even be seen at a glance in the nomenclature of the leading schools of Islamic jurisprudence that bear to this day the names of their individual eponyms, the Imams Abu Hanifa, Shafie, Malik, Ibn Hanbal, Ja'far al-Sadiq and so forth, founders of the madhhabs (legal schools) and scholastic centres that flourished in their names.

A great deal of what has been said so far has, however, changed in the course of time. The prevalence of the nation state model with its constitutionalist underpinnings and the fact that the legal theory of Islamic jurisprudence over ijtihād and $i j m \bar{a}$ ' etc., we have envisaged in our discussion above is no longer operative under the nation state model. The nation state model disrupted continuity of much that was Islamic in the realm of law and governance, the Shari'ah itself, and ideas and institutions of an Islamic constitutional order. Most of the postcolonial Muslim states were modeled on divergent legal theories and constitutions that barely refer to ijtihăd, ijma 's the umma, khilāfa, even the Shariah.

But even under the old executive-centralist model and the admitted continuity of many of the basic Islamic positions under the substantive Shari'ah, there still remains considerable scope for extra-Shari'ah legislation. The unprecedented disruptions and changes the Muslim world has experienced brings it face to face with new challenges to provide fresh interpretation of the source evidence in conjunction with newly arising issues of concern to law and governance. This may be elaborated as follows: 
1. That which has not been regulated by the existing Shari'ah, and which is known, in the fiqh jargon, as the unoccupied sphere (mantiqat al-firägh, also as mantiqat al- 'afw) and remains open to human legislation and ijtihād. This is the purport of a renowned hadith: "God has made certain things obligatory, so be sure not to neglect them; He has laid down certain limits, which you must not exceed; He has prohibited certain things which you must avoid; and He has, out of mercy but not forgetfulness, remained silent over other matters, so try not to be inquisitive about them." ${ }^{20}$ Qaradawi quotes this hadith side by side with the Qur'anic verse: "and your Lord is never forgetful." (Maryam, 19:64) Hence the conclusion that the Muslim community is free to regulate its own affairs in all areas that are not regulated by textual injunctions, such as science and technology, industrial relations and commerce, international relations, traffic regulations, administration and policy relevant matters etc., all of this and more may be open to siyasa-based initiative and legislation. Further support for this position is found in the Qur'anic proclamation that "God has expounded in detail all what He has forbidden to you" (al-An' am, 6:11) - thus implying that nothing is forbidden beyond what is clearly declared in God's messages. Note also the legal maxim that "permissibility is the basic norm (of Shari' ah) in all matters-al-așlu fi'l-ashyā' al-ibāha,a," and the hadith text that "Muslim are bound by their stipulations." ${ }^{21}$ Muslims are free to conclude contracts, enact laws and regulations that incur commitment provided always they do not conflict with the clear injunctions of Shari'ah. ${ }^{22}$

The foregoing also subsumes unregulated public interest (mașlaha mursala), which refers to matters of public interest that have not been regulated by the existing Shari'ah. Concerning all that which appears to be of benefit for the people, be it in the present or future, whether in temporal matters or in reference to the Hereafter, the authorities are empowered to take measures to secure the benefit in question whenever the opportunity arises. Such measures may consist of substantive law or siyāsa-based rules and procedures that may be introduced from time to time.

Mașlaha mursala is circumstantial and cannot therefore be generalised nor predicted in advance. Something that is deemed to be a mașlaha in one country may not be the same in another, nor even in the same country, for change of time and circumstance may alter the situation so that a mașlaha of the past is no longer the same under a different set of circumstances. Hence the wisdom and insight of capable leaders, consultative bodies and scholars play a role in the identification of mașlaha and also in the determination of measures through which it can be realised. The Companions took measures, for instance, to establish new government departments, build prisons, issue coins, introduce market regulations etc., on which the text was totally silent. 
Mașlaha is also an evolving concept that grows abreast with new changes in the life of the community and the legislative organ would be authorised to legislate over what they deem to be of benefit. ${ }^{23}$ This may be illustrated by reference to legislation, in recent times, that Muslim countries have introduced on compulsory registration of marriage and divorce as well as the sale and purchase of real property, municipal laws, guidelines and restrictions on urban planning, imports and exports, and more recently restrictions on smoking and so forth, all of which partake in mașlaha-based legislation and the scope remains open for legislative initiative. ${ }^{24}$

2. Matters over which the Shari' ah grants a choice to the head of state, such as in respect of treatment of the prisoners of war, where the text (Muhammad, 47:4) records several methods, one of which may be selected for purposes of enforcement. Also with regard to the perpetrators of highway robbery (hirāba) the text (al-Ma'idah, 5:33) records four types of punishment from the most to the least severe and the choice rests with the leader to select one he deems to be most appropriate. Differences of opinion also exist on whether death by retaliation (qișaș) is applicable to one who commits murder under duress: some say only one of the two parties is subject to retaliation but differ as to which, others say both are, and still others maintain that neither is subject to retaliation..$^{25}$

3. With regard to matters over which the jurists are in disagreement, be in the interpretation of text, or ijtihäd-based conclusions, the head of state may determine and select that which is deemed to be most appropriate. This is in accordance with the renowned legal maxim: "the command of the Imam puts an end to disagreement - amr al-imām yarfa' al-khiläf." In a similar maxim it is provided "the command of the Imam is enforceable - amr al-imām nafidh." ${ }^{26}$ Qur'an commentaries and fiqh manuals record many instances where the range of disagreement may be such that seven or eight different views are given by various schools and jurists. The head of state, the courts and the legislature, for that matter, would be in a position to select only the one that best serves the interest of the community for purposes of judgment and legislation. Disagreement is also found not only among the leading schools, but often within them and among their leading figures and followers. Note, for example, the extensive fiqh works, such as that of Ibn Maflah alHanbali's Kitāb a-l-Furū' in six volumes, and al-Mardawi, al-Inșāffi Masā 'āl al-Khiläf in twelve volumes, on the impressive range of scholastic diversity of schools and scholars over juristic issues. ${ }^{27}$ The authority of the head of state in such cases may be specified by a legislative instrument that takes from these resources a ruling that is deemed to be in the people's best interest. 


\section{The Judiciary}

Justice is a major preoccupation of Islam and its Shari'ah, and those who administer justice merit great spiritual distinction and reward. Qur'anic guidelines on justice maintain commitment to impartial justice and objectivity in its implementation. There are more that 50 verses in the Qur'an on justice ('adl, qist), and more than 300 on injustice and oppression (zulm). The scope of justice in the Qur'an and hadith subsume three varieties: corrective or retributive justice, distributive justice, and political justice as in the sphere of appointments of officials, international relations, war and peace etc. ${ }^{28}$

Historically, the ulama and religious leaders dominated the judicial branch, in the capacity mainly, however, of government employees. But since the Shariah was not enacted by the state, and the state had in effect an administrative capacity with regard to its enforcement, the ulama and judges regarded themselves as the custodians of Shari'ah and bearers of direct mandate to enforce it almost independently of the state hierarchy. In practice, however, judges were under the administrative control of governors and ministers.

Muslim commentators have held that no one is in principle authorised to influence the judge nor to compromise his independence as the effective administrator of Shari' ah, a task they have been mandated by the Qur' an (cf., al-Nisa', 4:59). In Zaydan's assessment, "no one whatsoever is permitted to interfere in the work of the Qadi with a view to influencing him away from the course of justice. Anyone who violates this guideline is violating the Shari' ah." ${ }^{29}$ This is because the duty to administer justice, although primarily borne by the head of state, and the judge acts as his deputy, the latter shares that function with him by virtue of a direct Shari' ah mandate.

Judgment ( $\left.q a d \bar{a}^{\prime}\right)$ is by definition a declaratory task that is vested in the judge; the latter ascertains the ruling of Shari'ah and declares its application to a dispute before him. The judge does not, in other words, create a ruling $(\mathrm{hukm})$ in the absence of any evidence in Shari'ah. This is a declaratory and interpretative role, and no one can effectively share it with the judge, who must issue judgment based on his own understanding and conviction. Since the judge is personally accountable for his error or miscarriage of justice, he must act independently of extraneous influences in the conduct of duty. He is within his rights also to reject all interference, even from the head of state himself, in the conduct of his judicial functions. ${ }^{30}$

Since almost every case before the court exhibits significant variation in respect of detailed circumstances surrounding it, judges are often called upon to carry out original interpretation (ijtiha d) of the basic evidence of Shari' ah to arrive at appropriate judgments. This is endorsed by the theory of ijtihadd, which demands 
total freedom for the judge and mujtahid to discharge their duty in accordance with their true conviction free of all interference. The judge is not even allowed to follow other judges in the deliverance of his own judgment and ijtihād, nor to deputise that task to anyone else. Should there be interference from the head of state or his leading officials, the judge is not under duty to comply. For according to the ruling of a renowned hadith "There is no obedience in transgression; obedience is due only in righteousness." ${ }^{31}$ It would be wrong for the head of state and other office holders of influence to interfere in the works of a judge that may undermine his independence. Yet historical records exhibit a wide gap between theory and practice, which show that judges were often denied their independence.

Commentators have stated that judges enjoyed considerable independence during the Rightly Guided Caliphs, and also during the Umayyad rule (665$750 \mathrm{CE}$ ) so much so that they issued judgments in disputes involving the caliph himself and have issued judgment against the caliph. ${ }^{32}$ Reports thus indicate that the caliphs 'Umar b. al-Khattab, and 'Ali b. Abi Talib appeared before the Qadi as parties to litigation, and both expressed the desire that they should not be given any preferential treatment by the court. This precedent sustains the conclusion, as one commentator points out, that the judge can accept a suit against the very person of the head of state and try him in an open court and that "this feature of the Islamic judiciary is an index of its independent status." ${ }^{33}$ Under the Umayyad rule, judges were free in the exercise of $i j t i h \bar{a} d$. The founder of this dynasty, the caliph Mu'awiya, was also the first to relinquish his judicial functions to appointed judges ${ }^{34}$ Another observer qualified this conclusion so as to say that "the judiciary was fully independent from the executive ... but this independence was confined to civil cases and private wrongs." ${ }^{35}$

The emergence and gradual crystallisation of the four schools of jurisprudence during the early Abbasid period around the eleventh century CE led to new restrictions on the independence of judges. The establishment of the leading schools was taken to imply that the Shari'ah had already been expounded and elaborated to an advanced level and that from then on everyone, including the judges, should follow the existing expositions of the schools and refrain from innovative interpretation and $i j t i h \bar{a} d$. A factor that prompted this development was the exceeding diversity of schools, interpretations and doctrines that were viewed with apprehension and thus a cause for concern that they could lead to confusion and unacceptable disparity in court decisions. The unprecedented expansion of the territorial domains of Islam also brought the Shari'ah into contact with other more entrenched cultures and traditions thus prompting the ulama to pronounce the so-called 'closure of the gate of ijtihād-sad bāb al-ijtihād'. This was partly why it became official policy of Islamic governments to adopt one or the other of the leading schools as their official madhhab. ${ }^{36}$ 
The new restrictions which limited the scope of ijtihād to a particular school clearly marked a departure from the precedent of the early caliphs and an unwelcome imposition on the freedom of judges. Al-Mawardi (d.450/1058), himself a judge and follower of the Shafi'i school, found this unacceptable when he expounded the doctrine and wrote that the judge must exercise his own ijtihād and, in so doing, he is not bound to adhere to the ruling of the school to which he subscribes. Should he be the follower of the Shafi'i school, he is not bound by the ruling of that school unless his own ijtihād leads him to it; should his ijtihäd favour the opinion of Abu Hanifah, then he should act on it without hesitation. ${ }^{37}$ The prominent Hanbali Jurist Ibn Qudama al-Maqdisi (d.1223/620) held it to be impermissible to appoint a judge on condition that he should adjudicate according to a particular school. "God the Most High has decreed righteousness as the criterion of justice and righteousness cannot be confined to a particular school. Hence when a judge is appointed with such a condition, that condition is null and void". ${ }^{38}$

A careful reading of the Qur'an also points to the need for an independent judiciary to adjudicate disputes between the ruler and ruled with total impartiality. This may entail the sensitive task of disqualifying the head of state when found to be in violation of his terms of office. This is envisaged in the Qur'an where the text anticipates the possibility of disputes arising between the ruler and ruled, which can only logically be adjudicated by a judicial authority that is not influenced by either of the disputing parties. This is our understanding of the Qur'anic verse, known as the ayat al-umarä' (the rulers' verse) to which a reference has already been made:

O you who believe! Obey God and obey the Messenger and those invested with authority among you. Should you dispute over a matter among yourselves, then refer it to God and to the Messenger ... That is better, indeed commendable in the end (al-Nisa', 4:59).

This text is clear on the point that both the ruler and ruled are subject to the ordinances of Shari' ah. It is also implied that people are entitled to disagree with their leaders. The context also indicates that the verse addresses the ruler and ruled. In the event of a dispute arising between them, then it is only logical that neither of the two parties would be authorised to adjudicate over it, which is why it should be objectively determined, as the text specifies, by reference to the Shari'ah. To facilitate the implementation of this text, there must be an independent judiciary with full powers to adjudicate disputes arising between the citizen and state. ${ }^{39}$ This may take the form of the historical Mazāilim (courts of grievances), which had jurisdiction over disputes involving state officials and judges themselves, or it 
may take the form, as we may have today, of an independent judiciary with clear constitutional mandate that grants it immunity against interference. It is essential in any case, that the head of state should have no powers to dismiss or replace the leading judges in the land, and that means a free and independent judiciary. ${ }^{40}$

Furthermore, the Islamic constitutional theory is explicit on the point that the community may depose the head of state in the event of a manifest aberration, when he commits a crime, or in the event of loss of mental and physical faculties. This begs the question as to who should make that momentous decision to disqualify a reigning head of state. The constitutional theory has not answered this question, but it may be said in response, that the judiciary is called upon to discharge the sensitive task of impeaching the errant head of state and eventually to declare him disqualified. This would be almost impossible unless the judiciary is fully independent and the judges enjoy total security of office. ${ }^{41}$

\section{Conclusion and Recommendations}

This article advanced an Islamic perspective on an aspect of western constitutional law that does not claim its origins in Islam, but which has been widely recognised and adopted by Muslim countries and constitutions - and it has as such become a part of the general custom ('urf 'aam), which is a recognised source of judgment in Islam. My enquiry into the Islamic sources also addressed the exaggerated assertion that separation of powers is un-Islamic, or anti-Islamic. I have shown that this is not the case. One can even ascertain a functional separation of powers in an Islamic polity. My other conclusions are:

- Separation of powers is an important instrument of checks and balances in the exercise of power and a central theme therefore of constitutionalism and government under the rule of law.

- Separation of powers is not a substantive principle of the Shariah, but a sub-theme of judicious policy (siyasah shar'iyyah), and open therefore to considerations of good governance and public interest (mașlaha).

- Muslim countries that have committed themselves to the principle of separation of powers in their constitutions are also bound under Shari'ah to observe it - as in the hadith that "Muslims are bound by their stipulations." Good constitutions are often adopted but not implemented, and even violated: examples may be Pakistan under president Musharraf, and Afghanistan under president Karzai.

- The locus of political authority in Islam is the community, ummah and people in every country, but the exercise of that authority is regulated by the constitution, which is essentially an instrument of limitations the people may choose to impose. 
- Separation of powers is not a monolithic idea in that it can take various forms and dimensions depending on the conditions and capabilities of particular states, their constitutional history and traditions. A country may subscribe to administrative centralism, presidential or parliamentary system, even federalism, yet also apply a regime of separation of powers.

- Islam envisages a consultative and participatory system of rule, which also means there should be greater coordination among the organs of power. When separation of powers is integrated in an Islamic polity and constitution, it should also be moderated by the concerns of coordination and unity of purpose among the various organs of state.

\section{Notes}

* Mohammad Hashim Kamali, Founding CEO of IAIS Malaysia, graduated from Kabul University, and took his $\mathrm{PhD}$ in Islamic and Middle Eastern Law at the University of London in 1969. Professor Dr M. H. Kamali served as Professor of Islamic Law and Jurisprudence at the International Islamic University Malaysia (IIUM, 1985-2007), then Dean of the International Institute of Islamic Thought and Civilization (ISTAC). $\mathrm{He}$ also held Visiting Professorships at McGill University's Institute of Islamic Studies; Capital University, Ohio; and the Wissenschaftskolleg, Berlin. A member of the Constitution Review Commission of Afghanistan (2003), he has provided expert legal consultation to the new constitutions of Iraq, the Maldives and Somalia. Eminent authority on Islamic legal studies, he has published over 150 academic articles and 35 texts, including standard textbooks at universities worldwide. He can be contacted at ceo@iais.org.my.

1. Cf., 'Abd al-Hamid Mutawalli, Mabādi Nizāom al-Hukm fi'l-Islām, Alexandria (Egypt); Mansha'at al-Ma'arif, 1974, p. 417; 'Abd al-Ghani Busyuni 'Abd Allah, Nazariyyat al-Dawla fi'l-Islām, Beirut: al-Dar al-Jami'iyya, 1986, 260. This binary fiqhi division of wilaya elaborates the Qur'anic concept of qawwamun (guardians) in al-Nisa' (4:35).

2. Cf., Mohammad Hashim Kamali, "Characteristics of the Islamic State," Islamic Studies 32 (1993), 17-40, at 31.

3. Cf., Qur'an: 28:26. See for details Basyuni 'Abd Allah, Nazariyyat al-Dawla, 224.

4. Cf., Sa'di Abu Habib, Dirāsah fi Minhāj al-Islām al-Siyāsī, Beirut: Mu'assasa alRisala, 1985, p. 72; Taqi al-Din al-Nabhani, Muqaddimat al-Dustur, Kuwait: Dar alQalam, 1964, 89-90.

5. 'Uthman Bin Ju'a Damiriya, "al-Sulțat al-'Āmma fi'l Islām: al-Mafhūm wa'l-'Ilāqa," Majalla Jamī' a al-Sharja li'l- 'Ulüm al-Shar'iya wa'l-Insāniyya, (Sharjah University Journal for Shari'ah and human sciences), vol. 3, no. 3 (1427/2006), 14.

6. Both Abu'l Hassan al-Mawardi (d. 1058 CE), and Abu Ya'la al-Farra' (d.1066) wrote books bearing the identical title: Kitāb al-Ahkām al-Sultāniyya (book on sultanic ordinances), which are recognised reference works on the subject.

7. Abu'l Hassan al-Mawardi, Kitäb al-Ahkkām al-Sulțāniyya, Cairo: Matba'a al-Sa'ada, 1959, p. 40. 
8. For more details on siyāsa shar'iyyah, see Mohammad Hashim Kamali, Shari'ah Law: An Introduction, Oxford: One World Publications, 2008, Ch. 11 entitled "Beyond the Shari' ah: an Analysis of Shari' ahh-oriented Policy (siyāsah shar 'iyyah), 225-246.

9. Abu'l Hassan al-Mawardi, Kitāb al-Ahkām al-Sulțāniyya, Cairo: Matba'a al-Sa'ada, $1959,30$.

10. 'Abd al-Hamid Mutawalli, Mabādi Niz̄ām al-Hukm fi'l Islām, Alexandria: Mansha't al-Ma'arif, 1974, 229. Busyuni 'Abd Allah, Nazariyyat al-Dawla fi'l-Islām, $254 \mathrm{f}$.

11. Basyuni 'Abd Allah, Nazariyyat al-Dawla, 260.

12. Al-Mawardi, al-Ahkām al-Sulțāniyya, 33.

13. See for details on accountability (muḥāsaba), Mohammad Hashim Kamali, Citizenship and Accountability of Government: an Islamic Perspective, the Islamic Texts Society, Cambridge, U.K, 2011, pp. 200-203. See also Busyuni 'Abd Allah, Nazariyyat al-Dawla fi'l-Islām, 261f.

14. Cf., 'Uthman Damiriya, "al-Sultat al- 'Amma fi'l-Islām," 11.

15. 'Abd al-Razzaq al-Sanhuri, Fiqh al-Khiläfa wa Tațwwruha. Arabic translation and commentary by Nadia al-Sanhuri and Tawfiq al-Shawi, Cairo: al-Ha'a al-Misriyya al-'Amma li-1-Kitab, 1989, 174-75.

16. Ibid, 179.

17. Cf. Mahmood Ahmad Ghazi, State and Legislation, Islamabad: Shariah Academy, 2006, 110.

18. Wahba al-Zuhaily, Qaḍ̄ya al-Fiqh wa'l-Fikr al-Islāmī, Damascus: Dar al-Fikr, 2006, $466 \mathrm{ff}$.

19. Ibid.

20. Quoted in Yusuf al-Qaradawi, al-Siyāsa al-Shar'iyya fi Daw'Nușuș al-Sharī'a wa Maqāșidiha, 2nd ed., Cairo: Maktaba Wahba, 2005/1426, 70. Hadith also recorded by Al-Nawawi in his Arba'in Hadith (forty select hadith).

21. Abu Dawud, Sunan Abu Dāwūd (Ahmad Hasan's tr,), Vol. III, 1020, hadith no. 3587.

22. See for a discussion, Mohammad Hashim Kamali, Islamic Commercial Law: An Analysis of Futures and Options, Cambridge (and Kuala Lumpur): Islamic Texts Society, 2000, 66-82.

23. See for details on mașlaha mursala M. H. Kamali, Principles of Islamic Jurisprudence, Cambridge: Islamic Texts Society, 2003, ch.13 (351-369). See also Qaradawi, alSiyāsa al-Shar'iyya, 82f.

24. Cf., 'Abd al-Ghani Busyuni 'Abd Allah, Nazariyya al-Dawla fi'l-Islām, Beirut: alDar al-Jami'iyya, 1986, $215 f$.

25. Cf., al-Qaradawi, al-Siyāsa al-Shar'iyya, 80.

26. See for details on the two legal maxims and the subject of $i k h t i l a \bar{f}$ generally, M. H. Kamali, Shari'ah Law: An Introduction, Oxford: Oneworld, 2008, Ch. 5 entitled "Disagreement (ikhtiläf) and Pluralism in Shari'ah," pp. 99-123 at 119. This maxim essentially derives from the Qur' anic verse on obedience to the leaders (ulu al-amral-Nisa', 4:59).

27. See for a discussion, al-Qaradawi, al-Siyāsa al-Shar 'iyya, 74-79.

28. For more details on justice see Mohammad Hashim Kamali, Freedom, Equality and Justice in Islam, Cambridge: Islamic Texts society, 2002, 103-155.

29. 'Abdal-Karim Zaydan, Nizām al-Qad̄̄' fi'l-Sharī'a al-Islāmiyya, 3rd revised ed., Beirut: Mu'assasah al-Risalah, 2002, 59.

30. Ibid., 59-60. 
31. Ibid., 60 .

32. Ibid., 61. See also Subhi Mahmassani, Arkān Huqūq al-Insān fi'l-Islām, Beirut: Dar al-'Ilm li'l-Malayin, 1979, 98.

33. Farooq Hassan, The Concept of State and Law in Islam, New York: University of America Press, 1981, 43.

34. Sulayman Muhammad al-Tamawi, al-Sulțat al-Thalath fì Dasātīr al-'Arabiyya wa fi'l-Fikr al-Siȳāsi al-Islāmī, Cairo: Dar al-Fikr al-'Arabi, 401.

35. Ghulam Murtaza Azad, Judicial System of Islam, Islamabad: Islamic Research Institute, 1987, 100.

36. See for detail Mohammad Hashim Kamali, "Appellate Review and Judicial Independence in Islamic Law," in ed. Chibli Mallat, Islam and Public Law, London: Graham \& Trotman, 1993, 49-85.

37. Abu'l Hassan 'Ali al-Mawardi, Kitāb al-Aḥkām al-Sultāniyya, Cairo: Matba'a alSa'ada, 1090/1327, 64.

38. Abu Muhammad 'Abd Allah Ibn Qudama al-Maqdisi, Al-Mughnī, Riyad: Maktaba al-Riyad al-Haditha, 1981/1401, vol. 9, 106.

39. Muhammad Asad, The Principles of State and Government in Islam, Los Angeles: California University Press, 1961, 66.

40. Cf., Mahmud 'Abd al-Majid al-Khalidi, Qawā'id Niẓām al-Hukm fi'l-Islām, Kuwait: Dar al-Buhuth, 1980/1400, 211.

41. Cf., Mohammad Hashim Kamali, “Appellate review and Judicial Independence in Islamic Law,” in ed. Chibli Mallat, Islam and Public Law, 51-52. 